\title{
PRODUCTION OF POLICLONAL ANTISERA SPECIFIC TO PLANT VIRUSES BY RABBIT ORAL IMMUNIZATION
}

\author{
J. ALBÉRSIO A. LIMA*, ROBERTO C.A. LIMA* \& M. FÁTIMA B. GONÇALVES \\ Universidade Federal do Ceará, Departaentode Fitotecnia, Laboratório de Virologia Vegetal, Campus do Pici, \\ Cx. Postal 6046, 60.451-970, Fortaleza, CE, Brasil, e-mail: albersio@ufc.br
}

(Aceito para publicação em 14/08/2001)

Autor para correspondência: J. Albersio A. Lima

LIMA, J.A.A., LIMA, R.C.A. \& GONÇALVES, M.F.B. Production of policlonal antisera specific to plant viruses by rabbit oral immunization. Fitopatologia Brasileira 26:774-777. 2001.

\begin{abstract}
Serological techniques are of great importance for plant virus identification and characterization. The major limiting factor for using these techniques for plant virus identification is the requirement of a good virus purified preparation to be used in immunizing animals for antiserum production. In the present study, two New Zealand rabbits were orally immunized with extracts from cowpea (Vigna unguiculata) plants systemically infected with Cowpea severe mosaic virus (CPSMV) and with extracts from papaya (Carica papaya) infected with Papaya lethal yellowing virus (PLYV). The leaf extracts were prepared in saline solution $0.15 \mathrm{M}$ in the rate of $1: 1(\mathrm{w} / \mathrm{v})$ and clarified by a centrifugation of $10,000 \mathrm{~g}$ for $10 \mathrm{~min}$. The clarified extracts containing the viruses were

orally administered to the New Zealand rabbits in two series of five daily doses of $1.0 \mathrm{ml}$ each. The obtained policlonal antisera were shown to be very specific to their respective viruses in double immunodiffusion and indirect ELISA. These seem to be the first antisera specific for plant virus obtained by rabbit oral immunization. The results open up some possibilities for producing antisera to plant viruses of difficult purification. It is a simple, fast and inexpensive method for production of antisera for plant viruses when compared to the traditional techniques that involve rabbit injections with purified virus preparations.

Additional Key words: serology, immunology, virus identification, CPSMV, PLYV.

\section{RESUMO \\ Produção de anti-soros policlonais específicos para vírus de plantas por imunização oral de coelhos}

As técnicas sorológicas são de grande importância na identificação de vírus, sendo que sua maior limitação na diagnose de viroses vegetais reside na dificuldade da purificação dos vírus para a produção de anti-soros. No presente trabalho, coelhos da raça Nova Zelândia Branco foram, individualmente, imunizados por via oral com extrato de plantas de caupi (Vigna unguiculata) infetadas pelo vírus do mosaico severo do caupi (Cowpea severe mosaic virus, CpSMV) e extrato de folhas de mamoeiro (Carica papaya) infetado com o vírus do amarelo letal (Papaya lethal yellowing, PLYV). Os extratos foram preparados em solução salina $0,15 \mathrm{M}$, na proporção de $1: 1(\mathrm{p} / \mathrm{v})$, clarificados a uma centrifugação de

10.000 g por 10 min e administrados oralmente aos coelhos em duas séries de cinco doses diárias de $1,0 \mathrm{ml}$ cada, com intervalo de dois dias entre cada série. Os anti-soros obtidos foram avaliados por difusão dupla em agar e ELISA indireto, tendo mostrado-se reativos com extratos de plantas infetadas, sem apresentar reação com extratos de plantas sadias. Embora com títulos baixos, os anti-soros apresentaram excelentes especificidades para extrato de plantas infetadas, criando perspectivas para produção de anti-soros contra vírus de plantas com boa imunogenicidade e de difícil purificação. Trata-se de uma técnica simples, rápida e barata para produção de anti-soro específico para vírus de plantas.
\end{abstract}

The major limiting factor for using serological techniques in plant virus identification is the requirement of a good virus purified preparation to be used in animal immunization for antiserum production. The chemical plant virus purification is an expensive and complicated process involving several stages that begins with the virus propagation in the greenhouse and continues through the different types

*CNPq fellowship of chemical treatments followed by differential centrifugation cycles (Walkey, 1985). Sometimes the virus is lost during the purification process or purified in a non satisfactory concentration for use in rabbit immunization.

Cowpea severe mosaic virus (CPSMV) is the only virus from the family Comoviridae, genus Comovirus that naturally infects cowpea [Vigna unguicualta (L.) Walp. subsp. unguiculta] in Brazil (Lima \& Santos, 1988), representing a serious problem for this leguminous crop in all regions where 
it is cultivated. The first isolate of CPSMV obtained in Ceará designated CPSMV-CE (Lima \& Nelson, 1977) showed to be very severe in several cowpea genotypes thus reducing the productivity of commercial cowpea cultivars by up to $86 \%$ (Lima \& Santos, 1988).

The Papaya lethal yellowing virus (PLYV) is an isometric virus detected for the first time in papaya (Caraica papaya L.) in the State of Pernambuco, Brazil. It is a very stable virus that probably belongs to the family Tombusviridae and possibly to the genus Tombusvirus (Camarço et al., 1998). A PLYV isolate obtained in Ceará was purified and serologically characterized (Lima et al., 1994; Camarço et al., 1998).

The objective of the present research was to produce policlonal antisera specific to CPSMV-CE and PLYV by rabbit oral immunizations with clarified infected plant extracts as a model to evaluate the system developed by Florindo et al. (1997) of oral immunization for production of plant virus antisera in mice.

An isolate of CPSMV-CE was increased in cowpea 'Pitiúba' plants maintained in greenhouse conditions and 10 $\mathrm{g}$ of systemically infected leaf tissues were ground in a mortar and pestle with a saline solution $0.15 \mathrm{M}$, at the rate of $1: 1 \mathrm{(w} /$ v). The obtained extract containing CPSMV-CE was clarified by a centrifugation of $10,000 \mathrm{~g}$ for $10 \mathrm{~min}$ and orally administrated to a New Zealand rabbit, using a needleless syringe in two series of five daily doses of $1.0 \mathrm{ml}$ each. A similar immunization process was repeated in another rabbit using extracts of PLYV infected papaya leaves. Fifteen days after the last immunizations, the rabbits were bled to obtain the respective policlonal antisera. The antisera were evaluated by double immunodiffusion and indirect enzyme-linked immunosorbent assay (ELISA) techniques, against their respective virus antigens, and extracts from healthy cowpea and papaya plants.

The obtained policlonal antisera were shown to be very specific to their respective viruses. The antiserum for CPSMVCE reacted with extracts of CPSMV-CE infected plants showing a titer of 124 in double immunodiffusion test without any reaction with extracts from healthy plants (Figure 1). The CPSMV-CE antiserum did not show good results in indirect ELISA, indicating that the virus particles probably did not adsorb well in the ELISA plates. On the other hand, good results were obtained in double sandwich ELISA using two antisera specific for CPSMV-CE obtained in rabbit and mice (data not shown).

The antiserum for PLYV was reactive to extracts of PLYV infected papaya plants in double immunodiffusion (Figure 1) and indirect ELISA (Figure 2), with titers of 1:124 and 1:2.000, respectively. No reaction was observed with extracts of healthy plants in double diffusion and a weak reaction in ELISA was easily absorbed (Figure 2).

These seem to be the first antisera specific for plant virus obtained by rabbit oral immunization. The results open up some possibilities for producing antisera to those plant viruses which are difficult to be purified. It is a simple, fast

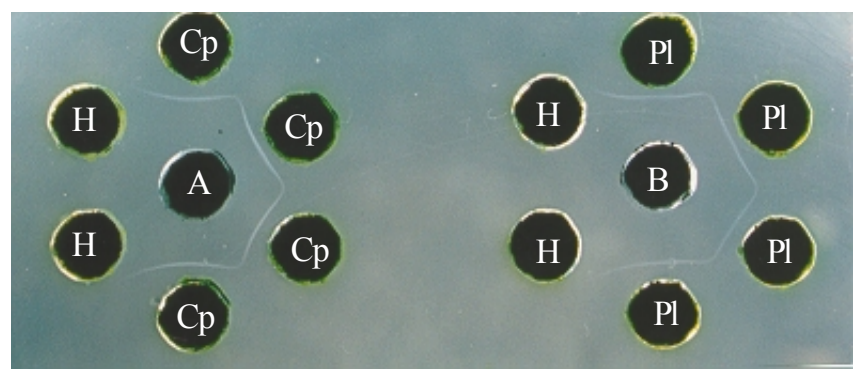

FIG. 1 - Double immunodifusion test with antiserum produced to Cowpea severe mosaic virus (CPSMV) and Papaya lethal yellowing virus (PLYV) by a rabbit oral immunization with extracts from infected plants. A - antiserum to CPSMV; B - antiserum to PLYV; Cp - extract from CPSMV infected plant; $\mathrm{PI}$ - extract from PLYV infected plant and $H$ - extract from healthy plant.

and inexpensive method for production of antisera for plant viruses when compared to the traditional techniques that involve rabbit injections with purified virus preparations.

The oral route has been widely used in human immunization since most pathogens start the infectious process by interacting with the mucosal, via the physiological entrance of food. According to Magistris (1998) a practical aspect of oral immunization is that it is a natural and noninvasive method. Oral immunization of an animal generally requires the administration of relatively large quantities of antigen, as the amount of antigen that is actually absorbed and capable of eliciting an immune response is usually low

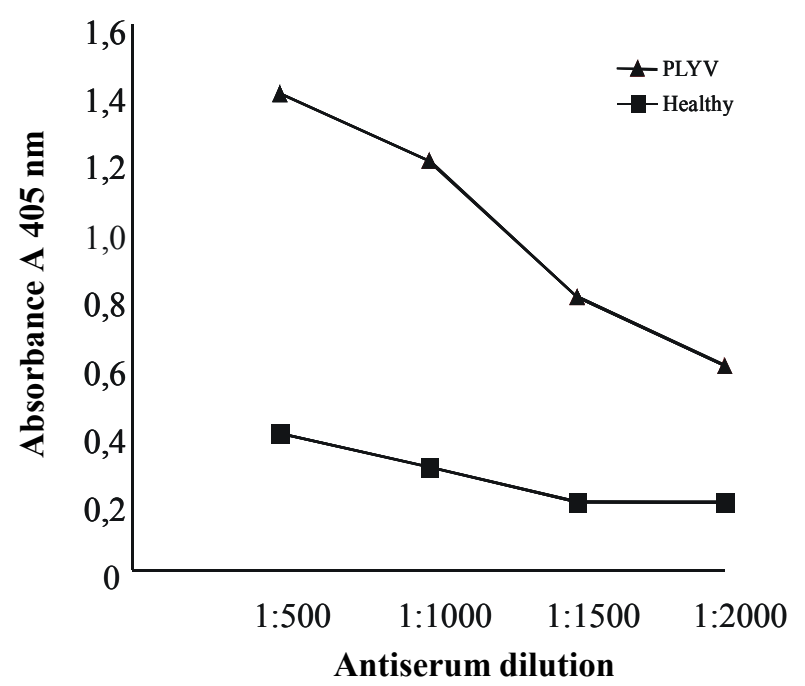

FIG. 2 - Indirect enzyme linked immunosorbent assay (ELISA) with antiserum specific to Papaya lethal yellowing virus (PLYV) produced by rabbit oral immunization, after absorption with plant health extracts. 
(Aizpurua \& Russel-Jones, 1988). As both viruses used in this study, CPSMV and PLYV, are found in very high concentration in their host tissue (Lima \& Santos, 1988; Camarço et al., 1998), this did not represent any problem for rabbit immunization.

According to Strobel \& Mowat (1998), small amounts of protein orally administered escape the enzymatic digestion in the intestine and are absorbed as intact antigens. For this reason, studies to increase antigen absorption and avoid its degradation are considered of great importance (Mestecky et al., 1997). As a small amount of antigen is usually absorbed by oral immunization, a large quantity of it may induce immune tolerance (Strobel \& Mowat, 1998). On the other hand, intermittent oral exposures to immunogens could not favour the oral tolerance phenomenon and may result in oral immunization expressed as the emergence of significantly high serum titers of specific antibodies (Verdolin et al., 2001).

The use of plants as systems for expression of foreign antigens has been increasingly evaluated as an inexpensive alternative for vaccine production (Arntzen \& Mason, 1995; Wigdorovitz et al., 1999). Tobacco mosaic virus (TMV) was used as a vector to express in Nicotina benthamiana Domin. plants the complete open reading frame coding for VP1, the major immunogenic protein of the food and mouth disease virus (FMDV). Mice intraperitoneally injected with leaf extracts prepared from those TMV-infected $N$. benthamiana plants developed specific antibody response to both TMV and PV1, and mostly importantly, the immunized mice developed a protective immune responses against an experimental challenge with virulent FMDV (Wigdorovitz et al., 1999). Similarly, a chimera of Cowpea mosaic virus (CPMV), the type member of the genus Comovirus, encoding an epitope derived from VP1 of FMDV was able to replicate in cowpea protoplast and plants (Usha et al., 1993). The modified protein produced in those cowpea plants reacted with FMDV specific antiserum, showing that CPMV could be used as a possibility for producing vaccines in plants using a RNA virus-based vector. Using more stable chimeric CPSMV produced with epitopes derived from human rhinovirus 14 (HRV-14) and human immunodeficiency virus type 1 (HIV-1), Porta et al. (1994) demonstrated that CPMV could be used as a highyielding system for the presentation of foreign peptide sequences.

The results of the present study with CPSMV and PLYV also demonstrated that as these viruses are very stable, replicate in very high concentration in their host cells and are very good immunogens to be used for oral immunization, they could also be used as virus-based vectors to express in plants, animal virus epitopes or complete protein for vaccine production.

\section{LITERATURE CITED}

AIZPURVA, H.J. \& RUSSEL-JONES, G.J. Oral vaccination. Identification of classes of proteins that provoke an immune response upon oral feeding, Journal of
Experimental Medicine. 167:440-451. 1988.

ARNTZEN, J.C. \& MASON, H.S. Oral vaccine production in the edible tissues of transgenic plants. In: Levine, M.M., Woodrow, G.C., Kaper, J.B. \& Coban, G.S. (Eds.) New generation vaccines. 2nd. Ed. Dekker, New York. 1995. pp.263-297.

CAMARÇO, R.F.E.A., LIMA. J.A.A. \& PIO-RIBEIRO, G. Transmissão e presença em solo do "papaya lethal yellowing virus". Fitopatologia Brasileira 23:453-458. 1998.

FLORINDO, M.I., SILVA, A.C.M., LIMA, J.A.A. \& SILVA LIMA, M. Produção de anticorpos em camundongos imunizados por via oral com vírus de planta. Fitopatologia Brasileira 22:335. 1997.(Resumo)

LIMA, J.A.A. \& NELSON, M.R. Etiology and epidemiology of mosaic of cowpea in Ceará, Brazil. Plant Disease Reporter 61:864-867. 1977.

LIMA, J.A.A. \& SANTOS, A.A. Viral diseases of cowpea in Brazil. In: Watt, E.E. \& Araujo, J. P.P. (Eds). Cowpea Research in Brazil. Brasília, IITA/EMBRAPA. 1988. pp. 213-32,.

LIMA, J.A.A., LIMA, A.R.T. \& MARQUES, M.L. Purificação e caracterização sorológica de um isolado do vírus do amarelo letal do mamoeiro solo obtido no Ceará. Fitopatologia Brasileira 19:437-441. 1994.

MAGISTRIS, M.T. Mucosal adjuvant effect of genetically modified cholera toxin and Escherichia coli heat- labile enterotoxin derivatives. Research Immunology 149:3335.1998.

MESTECKY, J., MICHALECK, S.M., MOLDOVEANU, Z. \& RUSSEL, M.W. Routes of immunization and antigen delivery systems for ptimal mucosal immune response en humans. Berhing Institute Metteilunge 98:33-43. 1997.

PORTA, C., SPALL, V.E., LOVELAND, J. JOHNSON, J.E., BARKER, P.J. \& LOMONOSSOFF, G.P. Development of cowpea mosaic virus as a highyielding system for the presentation of foreign peptides. Virology 202:949-955. 1994.

STROBEL, S. \& MOWAT, A.M.C.L. Immune responses to dietary antigens: Oral tolerance. Immunology Today 19:173-181. 1998.

USHA, R., ROHLL, J.B., SPALL, V.E., SHANKS, M., MAULE, A.J. JOHNSON, J.EW. \& LOMONOSSOFF, G.P. Expression of an animal virus antigenic site on the surface of a plant virus particle. Virology 197:366-374. 1993.

VERDOLIN, B.A., FICKER, S.M., FARIA, A.M.C., VAZ, N.M. \& CARVALHO, C.R. Stabilization of serum antibody responses triggered by initial mucosal contact with the antigen independently of oral tolerance induction. Brazilian Journal of Medical and Biological Research 34:211-219. 2001.

WALKEY, D. G. A. Applied plant Virology. Heinemann, Londres. 1985

WIGDOROVITZ, A., PEREZ FILGUEIRA, D.M., 
Production of policlonal antisera specific to plant viruses by rabbit...

ROBERTSON, N., CARRILlO, C., SADIR, A.M., MORRIS, T.J. \& BORCA, M.V. Protection of mice against challenge with foot and mouth disease virus (FMDV) by immunization with foliar extracts from plants with recombinant tobacco mosaic virus expressing the FMDV structural protein VP1. Virology 264:85-91. 1999. 